Ikha Ardianti, Mei Fitria Kurniati. Pengetahuan Perawat Tentang Attraumatic Care di RSU Ibnu Sina Bojonegoro

\title{
PENGETAHUAN PERAWAT TENTANG ATTRAUMATIC CARE DI RSU IBNU SINA BOJONEGORO
}

\author{
Ikha Ardianti ${ }^{1}$ \\ STIKes Insan Cendekia Husada Bojonegoro \\ Corresponding Author Email : ikhaardianti.icsada@gmail.com \\ Mei Fitria Kurniati ${ }^{2}$ \\ STIKes Insan Cendekia Husada Bojonegoro \\ Corresponding Author Email : meiok978@gmail.com
}

\begin{abstract}
ABSTRAK
Prosedur tindakan yang diterima anak merupakan stressor fisik yang dapat membuat anak tidak kooperatif, sehingga dapat menghambat intervensi keperawatan yang akan diberikan. Oleh karena itu penting bagi seorang perawat mengetahui prinsip attraumatic care dalam pemberi asuhan keperawatan pada anak. Attraumatic care adalah prinsip pemberian asuhan keperawatan yang bertujuan untuk mencegah trauma pada anak dan keluarga selama proses hospitalisasi. Tujuan penelitian yaitu mengetahui Mengetahui gambaran pengetahuan perawat tentang attraumatic care di di RSU Ibnu Sina Bojonegoro.

Desain penelitian menggunakan metode deskriptif kuantitatif dengan pendekatan Cross Sectional. Populasi dalam penelitian ini adalah seluruh perawat yang bekerja di RS Ibnu Sina Bojonegoro yang berjumlah 66. Penelitian ini dilakukan pada bulan April-Agustus 2019 sejumlah 32 dengan menggunakan purposive sampling.

Hasil penelitian menunjukkan tidak ada hubungan Usia dengan Kepatuhan Kontrol Gula Darah Pasien Diabetes Mellitus dengan nilai P- value 0.91. Tidak ada hubungan Jenis Kelamin dengan Kepatuhan Kontrol Gula Darah Pasien Diabetes Mellitus dengan nilai P- value 0.681 perawat yang memiliki tingkat pengetahuan tentang atraumatic care berada dalam kategori cukup yaitu sebanyak 14 orang $(43,8 \%)$, kategori baik sejumlah 9 orang $(28,1 \%)$ dan kategori kurang sejumlah 9 orang $(28,1 \%)$.

Anak yang tidak tidak kooperatif selama masa perawatan dapat memperlambat proses penyembuhan. Hal tersebut dapat dicegah dengan penggunaan prinsip atraumatic care dalam pemberian asuhan keperawatan. Oleh karena itu penting bagi seorang perawat mengetahui prinsip attraumatic care dalam pemberi asuhan keperawatan pada anak. sehingga bisa mencegah terjadinya komplikasi dan meminimalkan dampak hospitalisasi.
\end{abstract}

Kata Kunci : Umur, Jenis Kelamin, Diabetes Mellitus, Kepatuhan Kontrol

\section{ABSTRACT}

The procedure of action received by the child is a physical stressor that can make the child uncooperative, so that it can inhibit the nursing intervention that will be given. Therefore, it is important for a nurse to know the principle of attraumatic care in nursing care for children. Attraumatic care is a principle of nursing care that aims to prevent trauma to children and families during the hospitalization process. The purpose of the study is to know the knowledge of nurses about attraumatic care at RSU Ibn Sina Bojonegoro.

Research design uses quantitative descriptive methods with a Cross Sectional approach. The population in this study was all nurses who worked at Ibn Sina Bojonegoro Hospital which numbered 66. This study was conducted in April-August 2019 a number of 32 using purposive sampling.

The results showed no age association with blood sugar control compliance of diabetic mellitus patients with a value of $P$-value 0.91 . There is no gender relationship with blood sugar control compliance of diabetic mellitus patients with a value of $P$-value 0.681 nurses who have a level of knowledge about atraumatic care are in the category of enough 14 people (43.8\%), the good category of 9 people (28.1\%) and the category of less than 9 people (28.1\%).

An uncooperative child during the treatment period can slow down the healing process. This can be prevented by the use of the principle of atraumatic care in the provision of nursing care. Therefore, it is important for a nurse to know the principle of attraumatic care in nursing care for children. So that it can prevent complications and minimize the impact of hospitalization. 
Keywords : Age, Gender, Diabetes Mellitus, Blood Sugar Compliance

\section{PENDAHULUAN}

Anak adalah potensi masa depan bangsa, oleh karena itu sudah selayaknya setiap masyarakat ikut berperan serta dalam menjaga keoptimalan proses pertumbuhan dan perkembangan anak baik dalam keadaan sehat maupun selama sakit. Banyaknya prosedur tindakan yang diterima anak merupakan stressor fisik yang dapat membuat anak tidak kooperatif, sehingga dapat menghambat intervensi keperawatan yang akan diberikan. Oleh karena itu penting bagi seorang perawat mengetahui prinsip attraumatic care dalam pemberi asuhan keperawatan pada anak. Attraumatic care adalah prinsip pemberian asuhan keperawatan yang bertujuan untuk mencegah trauma pada anak dan keluarga selama proses hospitalisasi (Wong,2010).

Atraumatik care adalah bentuk perawatan terapeutik yang diberikan oleh tenaga kesehatan dalam tatanan pelayanan kesehatan anak, melalui penggunaan tindakan yang dapat mengurangi distress fisik seperti gangguan tidur, pembatasan aktifitas, suara bising dan perasaan nyeri, maupun distress psikologis seperti kecemasan, rasa takut, marah, kecewa, sedih, malu, dan rasa bersalah yang dialami anak maupun orang tua.

Anak sebagai individu yang masih dalam usia tumbuh kembang perlu perhatian lebih, karena masa anak merupakan proses menuju kematangan. Berbagai peristiwa yang dialami anak, seperti sakit atau hospitalisasi akan menimbulkan trauma pada anak seperti cemas, marah, nyeri, dan lainlain. Kondisi tersebut jika tidak ditangani dengan baik, akan menimbulkan masalah psikologis pada anak yang akan mengganggu perkembangan anak. Oleh karena itu, manfaat atraumatic care adalah mencegah masalah psikologis (kecemasan) pada anak, serta mengoptimalkan pertumbuhan dan perkembangan anak (Hidayat, 2012). Beberapa penelitian juga telah membuktikan bahwa penerapan atraumatic care memiliki pengaruh atau hubungan terhadap penurunan respon kecemasan pada anak yang di hospitalisasi (Bolin, 2011 \& Breving, et al., 2015).

United Nation Childrens Found memperkirakan lebih dari 5 juta anak di Indonesia mengalami hospitalisasi tiap tahunnya. Dari jumplah tersebut 35 per 1000 anak mengalami kecemasan dan stress. Berdasarkan hasil studi pendahuluan yang dilakukan oleh peneliti di RSU IbnuSina Bojonegoro tidak menerapkan prinsip attraumatic care saat memberikan asuhan keperawatan pada anak. Berdasarkanopservasi yang dilakukan peneliti didapati bahwa banyak anak yang menangis saat dilakukan tindakan keperawtan bahkan saat melihat perawat langsung menangis.Selain itu tampak orangtua yang makin cemas dan kebingungan saat anaknya dilakukan tindakan keperawatan tapi terus-menerus menangis dan tidak mau berpisah dengan orangtuanya. Hal ini menunjukkan bahwa anak mengalami trauma fisik dan psikologis.

Perawat sebagai salah satu anggota tim kesehatan, memegang posisi kunci untuk membantu orang tua menghadapi permasalahan yang berkaitan dengan perawatan anaknya di rumah sakit karena perawat berada di samping pasien selama 24 jam dan fokus asuhan adalah peningkatan kesehatan anak. Asuhan yang berpusat pada keluarga dan atraumatic care merupakan falsafah utama dalam pelaksanaan asuhan keperawatan anak. Oleh karena itu, upaya dalam mengatasi masalah yang timbul baik pada anak maupun orang tuanya selama dalam masa perawatan berfokus pada intervensi atraumatic care yang berlandaskan pada prinsip atraumatic care.

Ada beberapa faktor yang dapat mempengaruhi perawat dalam melaksanakan atraumatic care di rumah sakit. Notoadmodjo (2010) menyatakan bahwa ada dua faktor yang mempengaruhi pelaksanaan atraumatic care di rumah sakit, yaitu faktor internal dan faktor eksternal. Faktor internal tersebut adalah pengetahuan dan sikap anak tentang perawatan, sedang kan faktor eksternalnya adalah SDM yang dalam hal ini adalah perawat, pengetahuan dan kemampuan perawata melakukan asuhan dengan prinsip atraumatic care, kebijakan RS terkait pelaksanaan atau SOP asuhan keperawatan serta sarana dan prasarana yang dimiliki oleh RS.

\section{Tujuan Penelitian}

Tujuan Umum

Untuk mengetahui gambaran pengetahuan perawat tentang atraumatic care. 
Ikha Ardianti, Mei Fitria Kurniati. Pengetahuan Perawat Tentang Attraumatic Care di RSU Ibnu Sina Bojonegoro

Tujuan Khusus

a. Mengidentifikasi pengetahuan perawat tentang atraumatic care.

b. Mendeskripsikan pengetahuan perawat tentang atraumatic care.

\section{METODE PENELITIAN}

Desain penelitian menggunakan metode deskriptif kuantitatif dengan pendekatan Cross Sectional. Populasi dalam penelitian ini adalah seluruh perawat yang bekerja di RS Ibnu Sina Bojonegoro yang berjumlah 66 . Sampel dalam penelitian ini sebanyak 32 perawat. Teknik sampling yang digunakandalam penelitian yaitu purposive sampling yaitu pengambilan sampel dengan cara memilih sampel dari populasi sesuai dengan yang dikehendaki peneliti (tujuan/masalah dalam penelitian) (Nursalam, 2020). Instrumen pada penelitian ini menggunakan kuesioner tentang pengetahuan perawat terhadap atraumatic care. Penelitian ini dilakukan pada bulan April-Agustus 2019 sejumlah 32 dengan menggunakan purposive sampling. Kemudian data diolah dengan menggunakan analisis univariant.

HASIL

Data Umur Pasien

Tabel 1 Distribusi Frekuensi Responden Berdasarkan Usia

\begin{tabular}{ccc}
\hline Usia & $\mathrm{N}$ & $\%$ \\
\hline 23-30 tahun & 12 & 37,5 \\
\hline >30 Tahun & 20 & 62,5 \\
\hline Total & 32 & 100,0
\end{tabular}

Sumber : Data Penelitian 2019

Berdasarkan tabel 1 didapatkan dari 32 responden sebagian besar berumur $>30$ tahun yaitu sejumlah 20 responden $(62,5 \%$ ).

\section{Data Jenis Kelamin Pasien}

Tabel 2 Distribusi Frekuensi Responden berdasarkan Jenis Kelamin

Sumber : Data Penelitian 2019

\begin{tabular}{|c|c|c|}
\hline Jenis kelamin & $\mathrm{N}$ & $\%$ \\
\hline Laki-laki & 17 & 53,1 \\
\hline Perempuan & 15 & 46,9 \\
\hline Total & 32 & 100,0 \\
\hline
\end{tabular}

bahwa dari 32 responden, lebih dari
Sebagian berjenis kelamin laki-laki yaitu sebanyak 17 responden $(53,1 \%)$.

\section{Data Tingkat Pendidikan}

Tabel 3 Distribusi Frekuensi responden Berdasarkan Tingkat Pendidikan

Sumber : Data Penelitian 2019

\begin{tabular}{lll}
\hline Pendidikan & $\mathrm{N}$ & $\%$ \\
\hline D3 & 29 & 90,6 \\
\hline S1 & 3 & 9,4 \\
\hline S2 & 0 & 0 \\
\hline Total & 32 & 100,0 \\
\hline \multicolumn{2}{r}{ Berdasarkan tabel 3 menunjukkan }
\end{tabular}

bahwa mayoritas responden berpendidikan D3, yaitu sejumlah 29 responden (90,6\%).

\section{Data Tingkat Pendidikan}

Tabel 4 Distribusi Frekuensi responden Berdasarkan Unit Kerja

\begin{tabular}{lll}
\hline Unit Kerja & $\mathrm{N}$ & $\%$ \\
\hline IGD & 8 & 25 \\
\hline Rawat Inap & 24 & 75 \\
\hline Total & 32 & 100,0 \\
\hline
\end{tabular}

Sumber : Data Penelitian 2019

Berdasarkan tabel 4 menunjukkan bahwa mayoritas responden unit kerjanya adalah ruang rawat inap, yaitu sejumlah 24 responden $(75 \%)$.

\section{Gambaran Pengetahuan Perawat}

Tabel 4 Gambaran pengetahuan perawat tentang Attraumatic Care

\begin{tabular}{ccc}
\hline Pengetahuan & $\mathrm{N}$ & $\%$ \\
\hline Baik & 9 & 28,1 \\
\hline Cukup & 14 & 43,8 \\
\hline Kurang & 9 & 28,1 \\
\hline Total & 32 & 100,0 \\
\hline
\end{tabular}

Berdasarkan tabel diatas dapat diketahui bahwa sebagian besar responden memiliki pengetahuan yang cukup tentang attraumatic care yaitu sebanyak $43,8 \%$, pengetahuan baik sebanyak28,1\% dan pengetahuan kurang sebanyak $28,1 \%$.

\section{PEMBAHASAN}

1. Pengetahuan Perawat tentang Attraumatic Care berdasarkan karakteristik responden 
Hasil penelitian tentang tingkat pengetahuan perawat tentang atraumatic care di RS. Ibnu Sina Bojonegoro menunjukkan perawat yang memiliki tingkat pengetahuan tentang atraumatic care berada dalam kategori cukup yaitu sebanyak 14 orang $(43,8 \%)$, kategori baik sejumlah 9 orang $(28,1 \%)$ dan kategori kurang sejumlah 9 orang $(28,1 \%)$. Pengetahuan adalah merupakan hasil "tahu" dan ini terjadi setelah orang mengadakan penginderaan terhadap suatu objek tertentu(Notoatmojo, 2010), pengetahuan juga berarti segala sesuatu yg diketahui; kepandaian: atau segala sesuatu yg diketahui berkenaan dengan hal (mata pelajaran) (KBBI, 2012). Pengetahuan yang dimaksud dalam penelitian ini adalah pengetahuan perawat tentang atraumatic care. Pelayanan Atraumatic care merupakan bentuk perawatan terapeutik tatanan pelayanan kesehatan anak melalui penggunaan tindakan yang mengurangi distres fisik maupun distres psikologis yang dialami anak maupun orang tua (Supartini, 2014). Terbentuknya pengetahuan individu tidak terlepas dari berbagai faktor yang mempengaruhi antara lain usia, lama kerja, pendidikan dan jenis kelamin.

Hasil penelitian menunjukkan bahwa Sebagian besar responden berusia $>30$ tahun yaitu sebesar $62,5 \%$, dan sisanya responden berusia $23-30$ tahun sebesar $37,5 \%$. Seiring dengan bertambahnya usia maka seseorang akan mengalami perubahan baik secara fisik, mental maupun emosional dan merupakan ciri kedewasaan fisik dan kematangan kepribadian yang erat hubungannya dengan pengambilan keputusan. Peneliti berpendapat bahwa pada usia dewasa awal akan mempengaruhi pengetahuan dan pengalaman yang dimiliki sehingga akan mempengaruhi terhadap persepsi individu terhadap pelayanan kesehatan yang digunakan. Hal ini akan memberikan konstibusi terhadap pelayanan kesehatan yang diterimanya berupa kepuasan hingga loyalitas terhadap rumah sakit.

Untuk data tentang jenis kelamin , didapatkan sebanyak $53,1 \%$ responden berjenis kelamin laki-laki, sedangkan sisanya $46,9 \%$ responden berjenis kelamin perempuan. Dilihat dari latarbelakang pendidikan dari 32 responden, diketahui bahwa mayoritas pendidikan responden adalah D3 yaitu sebanyak $90,6 \%$ dan sisanya sebanyak $9,4 \%$ responden berpendidikan $\mathrm{S} 1$. Semakin tinggi pendidikan seseorang, semakin mudah orang tersebut menerima informasi, dan semakin banyak pula pengetahuan yang didapat (Notoatmojo, 2007). Mayoritas perawat di rumah sakit Ibnu Sina bojonegoro berpendidikan D3 keperawatan mempunyai pengetahuan yang cukup tentang attraumatic care.

Apabila dilihat dari pengalaman kerja didapatkan lebih dari sebagian besar responden memiliki masa kerja 510 tahun yaitu sebanyak $53,1 \%$ dan sisanyasebanyak46,9 \% memiliki masa kerja 1-5 tahun. pengalaman belajar dalam bekerja memberikan pengetahuan dan keterampilan professional selama bekerja sehingga dapat mengembangkan kemampuan menagambil keputusan dalam bidang kerjanya, maksudnya adalah individu akan mampu mengembangkan pengetahuan yang dimilikinya dari lingkungan sekitarnya, dimana tidak hanya didapat dari pendidikan formal seperti jenjang pendidikan, namun pengetahuan juga dapat bertambah melalui pengalaman kerja, dan dengan adanya saling tukar pengalaman keterampialan dan ilmu pengetahuan antara antara perawat (Sujono, 2015).

\section{Pengetahuan perawat tentang menurunkan atau mencegah dampak perpisahan dari keluarga.}

Berdasarkan penelitian didapatkan hasil bahwa rata-rata responden mampu menjawab pertanyaan dengan kategori benar sebanyak $(75,0 \%)$, pada dasarnya setiap asuhan yang diberikan pada anak di rumah sakit memerlukan keterlibatan orang tua keberadaan anggota keluarga yang lain dan waktu kunjungan bagi orang tua harus terbuka selama 24 jam karena anak membutuhkan orang tua selama proses hospitalisasi (Supartini, 2012)

Untuk meminimalkan reaksi hospitalisasi yang timbul pada anak, pendekatan yang dilakukan perawat 
kepada orang tua adalah menganjurkan pada orang tua untuk tidak meninggalkan anak dalam keadaan sendiri, menganjurkan pada orang tua untuk menitipkan pada perawat apabila akan ditinggal, menganjurkan orang tua untuk bergantian dalam menunggu anak yang sakit seperti melibatkan saudara, teman atau yang lainnya, agar anak tidak merasa bosan, membantu orang tuanya mengambilkan obat (Rufaidah \& Agustin, 2012). Pendekatan yang dapat dilakukan perawat adalah dengan melibatkan orang tua dan biarkan hadi sebelum dilakukan prosedur. Pada tindakan/ prosedur yang menimbulkan nyeri, keluarga/ orang tua dipersiapkan untuk membantu, mengobservasi atau menunggu di luar ruangan (Wong, 2009).

3. Pengetahuan perawat tentang meningkatkan kemampuan orang tua dalam mengontrol perawatan pada anak.

Dari hasil penelitian diketahui bahwa rata-rata perawat mampu menjawab item pertanyaan dengan kategori benar sebanyak (66\%), reaksi keluarga selama anak dirawat di rumah sakit akan menimbulkan perasaan bersalah, ketidakberdayaan, dan cemas (Supartini, 2012). Keluarga merasa bahwa mereka telah melakukan kesalahan karena anaknya menjadi sakit. Perasaan tersebut muncul pada saat orang tua, ketika melihat anaknya mendapat prosedur yang menyakitkan seperti pengambilan darah, injeksi, infus dan prosedur invasive lainnya. Perawat dapat mendiskusikan dengan keluarga tantang kebutuhan anak, membantu orang tua dalam mengidentifikasi alasan spesifik dari perasaan dan responnya terhadap stress, memberikan kesempatan pada orang tua untuk mengurangi beban emosinya (Wong, 2009). Memberikan informasi merupakan salah satu intervensi keperawatan yang penting adalah sehubungan dengan penyakit, pengobatan serta prognosa, reaksi emosional anak terhadap sakit dan dirawat, serta reaksi emosional anggota keluarga terhadap anak yang sakit dan dirawat.

4. Pengetahuan perawat tentang mencegah atau mengurangi cedera

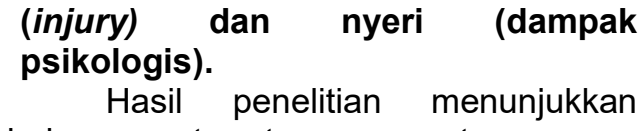
bahwa rata-rata perawat mampu menjawab item pertanyaan dengan kategori benar sebanyak $(65.50 \%)$, secara umum, persiapan anak-anak untuk menghadapi prosedur yang menyakitkan dapat menurunkan ketakutan mereka, dan manipulasi teknik prosedural anak-anak disetiap kelompok umur juga dapat meminimalkan ketakutan akan cedera tubuh (Wong, 2009).

Pendekatan yang dapat dilakukan adalah dengan memberikan penjelasan pada anak yang disesuaikan dengan tahap perkembangannya secara singkat, sederhana dan lakukan sesaat sebelum prosedur dikerjakan, memberikan fasilitas boneka atau mainan kesayangan dapat digunakan untuk membantu dalam menjelaskan prosedur yang akan dilakukan, merpersiapkan anak untuk menghadapi prosedur sesuai dengan tingkat pemahaman, menjawab setiap pertanyaan dan jelaskan tujuan dari setiap tindakan yang dilakukan, memberikan pelukan dan sentuhan rasa nyaman diperlukan setelah prosedur yang menyakitkan, membatasi penggunaan restrain gunakan bila perlu, menghargai kebutuhan anak akan privasi (Rufaidah \& Agustin, 2012). Pengkajian nyeri merupakan komponen penting dari proses keperawatan. Nyeri adalah apa pun yang dikatakan oleh orang yang mengalaminya, ada pada saat orang tersebut mengatakan bahwa itu terjadi (Wong, 2009). Proses penghilangan rasa nyeri sering tidak bisa dihilangkan secara cepat akan tetapi dapat dikurangi melalui berbagai teknik misalnya distraksi, relaksasi, dan imaginary. Apabila tindakan tidak dilakukan maka cedera dan nyeri akan berlangsung lama pada anak sehingga dapat mengganggu pertumbuhan dan perkembangan anak (Hidayat, 2005).

\section{Pengetahuan perawat tentang tidak melakukan kekerasan pada anak} Hasil penelitian menunjukkan bahwa rata-rata perawat mampu menjawab pertanyaan dengan kategori benar sebanyak $(72,80 \%)$, dari hasil ini dapat dilihat bahwa pengetahuan 
perawat berkaitan dengan tidak melakukan kekerasan pada anak adalah yang paling rendah dibandingkan dengan empat prinsip atraumatic care yang lain, kemungkinan ini terjadi karena masih kurangnya pengetahuan perawat terkait prinsip tidak melakukan kekerasan pada anak, ini didukung hasil observasi yang yang dilakukan oleh peneliti kepada 4 orang pasien dimana mereka terlihat takut dan menangis saat akan dilakukan tindakan medis seperti menyuntik, dan memasang infus.

6. Pengetahuan perawat tentang modifikasi lingkungan fisik.

Hasil penelitian menunjukkan bahwa rata-rata perawat mampu menjawab pertanyaan dengan kategori benar sebanyak (86\%), dengan modifikasi lingkungan fisik yang bernuansa anak dapat meningkatkan keceriaan, perasaan aman, dan nyaman bagi lingkungan anak sehingga anak selalu berkembang dan merasa nyaman di lingkungannya (Hidayat, 2005).

Untuk mengatasi ketakutan dan kecemasan anak akibat berada dilingkungan yang asing yaitu dengan cara lingkungan perawatan dibuat suasana yang gembira bagi anak dengan dekorasi yang menarik, misalnya dengan menempelkan gambar-gambar seperti; gambar binatang, boneka, bunga, mobilmobilan, kartun, buah-buahan dan lainlain pada dinding sesuai dengan selera anak, dinding tidak selalu dicat putih, alat-alat tenun juga tidak selalu berwarna putih sehingga anak tidak merasa bosan dan akan merasa nyaman didalam ruangan tersebut (Rufaidah \&Agustin, 2012).

\section{KESIMPULAN}

Berdasarkan hasil penelitan dan analisis pembahasan yang telah dijabarkan pada bab sebelumnya, dapat disimpulkan yaitu tingkat pengetahuan perawat tentang atraumatic care di RS. Ibnu Sina Bojonegoro menunjukkan perawat yang memiliki tingkat pengetahuan tentang atraumatic care berada dalam kategori cukup yaitu sebanyak 14 orang $(43,8 \%)$, kategori baik sejumlah 9 orang $(28,1 \%)$ dan kategori kurang sejumlah 9 orang $(28,1 \%)$.

\section{SARAN}

1. Bagi Perawat

Agar perawat dapat lebih meningkatkan pengetahuannya tentang atraumatic care sehingga akan meningkatkan kualitas pelayanan di rumah sakit.

2. Bagi layanan kesehatan

Diharapkan pihak rumah sakit mengadakan seminar atau pelatihanpelatihan terkait prinsip atraumatic care, untuk dapat meningkatkan pengetahuan attraumatic care perawat tersebut.

3. Peneliti selanjutnya

Diharapkan hasil penelitian ini bisa digunakan untuk acuan untuk melakukan penelitian dan sebagai pertimbangan bagi peneliti yang akan datang tentang hal-hal yang berhubungan dengan asuhan keperawatan dan atraumatic care.

\section{DAFTAR PUSTAKA}

Alligood,M.R., Tomey, A.M. (2010). Nursing theorists and their work. Mosby

Alligood, Martha Raile. (2006). Nursing theory: utilization and application. Elsevier-Mosby

Alimul, H. Aziz. (2009). Metode Penelitian Keperawatan \& Teknik Analisis Data. Jakarta : Salemba Medika

Aprilia, E. H. (2008). Tingkat Kepuasan Pasien Rawat Jalan terhadap Kualitas Pelayanan Instalasi Farmasi Rumah Sakit Umum Kabupaten Sragen.

Ardianti, I. (2016). Pengaruh Pemberian Buku Saku Perkembangan TerhadapUpaya Ibu dalam Memantau Perkembangan Anak Usia 1-3 Tahun. Jurnal IImu Kesehatan MAKIA, 10(2), 81-83.

. (2016). Pengaruh Penyuluhan Terhadap Respon Psikososial Keluarga Pasien Yang dirawat di Ruamg ICU RSUD DR Sosodoro Djatikoesoemo Bojonegoro. Jurnal IImu Kesehatan MAKIA, 1(1), 22-26. 
Ikha Ardianti, Mei Fitria Kurniati. Pengetahuan Perawat Tentang Attraumatic Care di RSU Ibnu Sina Bojonegoro

Arikunto, Suharsini. 2010. Prosedur Penelitian Suatu Pendekatan Praktik. Jakarta : Rineka Cipta.

Budiono., Pertami, S.U. (2016). Konsep Dasar Keperawatan. Jakarta : Bumi Medika

Hidayat, A.A. (2005). Pengantar ilmu keperawatan anak 1. Jakarta: Salemba Medika

Hidayat, A.Aziz Alimul., Uliyah, Musrifatul. (2016). Buku Ajar Ilmu Keperawatan Dasar. Jakarta : Salemba Medika

KBBI Draing. (2012).Kamus besar bahasa Indonesia. Diakses tanggal 28 Juli 2019

http://bahasa.kemdiknas.go.id/kbbi/in dex.php

Kodim, Yulianingsih. (2015). Konsep Dasar Keperawatan. Jakarta: CV.Trans Info Media

Maghfuroh, L. (2017). Atraumatic Care Menurunkan Kecemasan Hospitalisasi pada Anak Prasekolah di Ruang Anggrek RSUD dr. Soegiri Lamongan. Sain Med, 74.

Maryunani, Anik. (2015). Kebutuhan Dasar Manusia. Bogor : In media

Notoatmodjo, S. (2012). Metodologi Penelitian Kesehatan. Jakarta: Salemba Medika

Notoatmodjo, S. (2007). Promosi Kesehatan dan IImu Perilaku. Jakarta: Rineka Cipta.

Nursalam. (2012). Manajemen Keperawatan Aplikasi dalam Praktik Keperawatan. Profesional. Salemba Medika. Jakarta
(2013). Metodelogi Penelitian IImu Keperawatan Pendekatan Praktis. Jakarta: Salemba Medika

Nursalam \& Pariani. (2014). Pendekatan Praktis Penyusunan Metodologi Riset Keperawatan. Sagung Seto. Surabaya

Perry, Potter. (2006). Buku Ajar Fundamental Keperawatan. Edisi 4. Jakarta : EGC

Pohan, Imbalo S. (2013). Jaminan Mutu Layanan Kesehatan. Jakarta: EGC.

Rini, D. M. (2013). Hubungan Penerapan Atraumatic Care dengan Kecemasan Anak Prasekolah Saat Proses Hospitalisasi di RSU dr. H. Koesnadi Kabupaten Bondowoso.

Rufaidah, \& Agustin, W.R.(2012). Studi fenomenologi : pendekatan perawat dalam mengatasi kecemasan dan ketakutan pada anak usia pra sekolah akibat hospitalisasi di rumah sakit umum daerah kota semarang.

Santoso, T. (2014). Pengetahuan perawat tentang atraumatic care di rs pku muhammadiyah bantul dan yogyakarta.

Sastroasmoro, S \& Ismail, S. (2014). Dasardasar Metodologi Penelitian Klinis. Edisi ke-3. Sagung Seto. Jakarta

Surastiningsih, N. (2014). Gambaran pengetahuan perawat tentang atraumatic care di ruang rawat anak RSAB Harapan Kita Jakarta $=$ Overview of a traumatic care nurse in pediatric ward RSAB Harapan Kita Hospital Jakarta.

Supartini, Yupi. (2012). Konsep dasar keperawatan anak. Jakarta: EGC

Sujono. R. (2005). Kepuasan kerja perawat yang professional. Diakses pada tanggal 14 Juni 2014 http://www.Irc- 
Ikha Ardianti, Mei Fitria Kurniati. Pengetahuan Perawat Tentang Attraumatic Care di RSU Ibnu Sina Bojonegoro

kmpk.ugm.ac.id/id/UP-

PDFworking/no.170408.pdf

Supartini, Yupi. Buku Ajar Konsep Dasar

Keperawatan Anak. Jakarta: EGC.

2004.

Sugiyono. (2010). Statistika untuk

Penelitian. Alfabeta. Bandung

Sugiono. (2011). Metode Penelitian Kuantitatif Kualitatatif dan $R \& D$. CV Bandung : Alfabeta

Tarwoto \& Wartonah. (2015). Kebutuhan Dasar Manusia dan Proses Keperawatan. Jakarta : Salemba Medika

Wong, D, L. (2009). Buku ajar keperawatan pediatrik volume 2. Jakarta: EGC. 